\title{
Some Morpho-genetic and Behavioural Traits Among the Assamese Sikhs
}

\author{
Jaswant Singh and Sarthak Sengupta
}

\section{INTRODUCTION}

Population diversity provides a unique opportunity to study the morpho-genetic variation among the endogamous populations living in different geographical and ecological conditions (Bhasin and Khanna, 1994). The occurrence of the frequency distribution of morphological , genetical and behavioural traits among the people of Indian region have been compiled by Bhasin et al. (1992). The study reveals dearth of data from the people of North East India.

In the present note an attempt has been made to study few morpho-genetic and behavioural traits like $\mathrm{ABO}$ blood groups, $\mathrm{Rh}$ factors, cerumen type, tooth occlusion pattern, earlobe attachment, digital formulae, relative length of toes, middle phalangeal hair, hand clasping and arm folding among the Assamese Sikh, a numerically small population groups living in Nowgong district of Assam.

History of migration of the Sikh population to Assam took place at different period of time, and can be dated back as early as 1670 AD. After migration to the alien place, in course of time they mingled with the indigenous Assamese people through intermarriages and thus a mongrel community sprang up who prefer to identify themselves as Assamese Sikh.

\section{MATERIAL AND METHOD}

Data for the present study on the Assamese Sikh were collected from Borkola village of Nowgong district, Assam. Data on ABO and Rh blood groups were collected from 104 unrelated subjects following the standard methods suggested by Lawler and Lawler (1951). The gene frequencies were calculated according to Bernstein (1930). Cerumen types (dry and wet) were determined by visual examination. Tooth occlusion pattern were classified following Eveleth's (1972) four fold models. The two fold classification of earlobe attachment types of Powell and Whiteney (1937) is followed in the present study. Information on digital formulae were collected in order of relative position of the tips on index and annularis and recorded as $2>4,2<4$, and $2=4$ respectively. Three fold classification of digital formulae of toes (T, F and O ) of Minami (1952) adhered in the present study. Lutz's (1908) technique on the observation of hand clasping was followed in the present investigation. The type of arm folding were categorised following Weiner (1932). The presence of middle phalangeal hair was determined following Danforth (1921).

\section{RESULTS AND DISCUSSION}

The Assamese Sikh has the highest frequency of group $\mathrm{O}(37.5 \%)$ followed by group A $(29.81 \%)$, group B $(24.04 \%)$ and group $A B$ $(8.65 \%)$ respectively. The test of goodness of fit indicates that the population is in genetic equilibrium in respect of $\mathrm{ABO}$ blood group system (chi-square $=0.1971)$. The allele frequency had the order of $O(0.6064)>A$ $(0.2147)>B(0.1789)$ in them.

Of the 104 individuals tested, 7 were found to be Rh negative, giving a frequency of $6.73 \%$ for the phenotype. The incidence of $d$ allele 0.2594 .

Dry / flaky cerumen is highly frequent in the males $(61.54 \%$, gene $=0.7845)$, while the wet or waxy type predominates in females $(55.77 \%$, gene $=0.3349)$. Chi-square test shows nonsignificant variation (chi-square $=3.124$, d.f. $=1$, $0.10>\mathrm{P}>0.05$ ) between the two sexes.

The frequency of mild overbite type of tooth occlusion is found to be the highest (male $=1$ $44.90 \%$, female $=54.00 \%$ ) which is closely followed by edge to edge bite (male $=36.73 \%$, female $32.0 \%$ ). The incidence of negative overbite is observed more in male $(16.33 \%)$ than females $(10.00 \%)$. The severe overbite type is rare among them $($ male $=2.04 \%$, female $=4.00 \%$ ). Bisexual variation reveals nonsignificant differences (chi-square $=1.85$, d.f. $=1,0.80>\mathrm{P}$ $>0.70$ ) among them.

The frequency of free earlobe $(83.65 \%)$ is higher than attached earlobe $(16.35 \%)$. In 
Table 1: Phenotype and allele frequencies of blood groups among Assamese Sikh (N=104)

\begin{tabular}{|c|c|c|c|c|c|}
\hline $\begin{array}{l}\text { Blood group } \\
\text { phenotype }\end{array}$ & $\begin{array}{c}\text { Absolute } \\
\text { number }\end{array}$ & $\begin{array}{c}\text { Percentage } \\
(\%)\end{array}$ & $\begin{array}{c}\text { Expected } \\
\text { number }\end{array}$ & Allele & $\begin{array}{c}\text { Allele } \\
\text { frequencies }\end{array}$ \\
\hline $\mathrm{O}$ & 39 & 37.50 & 38.24 & $O$ & 0.606 \\
\hline A & 31 & 29.81 & 31.87 & $A$ & 0.215 \\
\hline B & 25 & 24.04 & 25.89 & $B$ & 0.179 \\
\hline $\mathrm{AB}$ & 9 & 8.65 & 07.99 & & \\
\hline $\mathrm{Rh}(+\mathrm{ve})$ & 97 & 93.27 & & $D$ & 0.7406 \\
\hline Rh (-ve) & 7 & 6.73 & & $d$ & 0.2594 \\
\hline
\end{tabular}

Chi-square $=0.1971$, d.f $=1,0.10>\mathrm{P}>0.5$

Table 2: Percentage distribution of morphogenetic traits among the Assamese Sikh

\begin{tabular}{|c|c|c|c|c|}
\hline Characters & \multicolumn{2}{|l|}{ Male } & Female & $M+F$ \\
\hline \multicolumn{5}{|l|}{ Tooth Occlusion Pattern } \\
\hline Edge to edge & 36.73 & \multicolumn{2}{|c|}{32.00} & 34.34 \\
\hline Mild overbite & 44.89 & \multicolumn{2}{|c|}{54.00} & 49.49 \\
\hline Severe overbite & 2.04 & \multicolumn{2}{|c|}{4.00} & 3.03 \\
\hline \multirow[t]{3}{*}{ Negative overbite } & 16.32 & \multicolumn{2}{|c|}{10.00} & 13.13 \\
\hline & \multicolumn{2}{|c|}{ Male } & \multicolumn{2}{|c|}{ Female } \\
\hline & $R$ & $L$ & $R$ & $L$ \\
\hline \multicolumn{5}{|c|}{ Relative Length of Fingers } \\
\hline $2>4$ & 5.76 & 11.53 & 11.53 & 30.76 \\
\hline $4>2$ & 86.53 & 80.76 & 86.53 & 59.61 \\
\hline $2=4$ & 7.69 & 7.69 & 1.92 & 9.61 \\
\hline \multicolumn{5}{|l|}{ Relative Length of Toes } \\
\hline Tibial $/ 1>2$ & 67.30 & 75.00 & 51.92 & 69.23 \\
\hline Fibular $/ 2>1$ & 32.69 & 23.07 & 44.23 & 26.92 \\
\hline $\mathrm{O} / 1=2$ & - & 1.92 & 3.84 & 3.84 \\
\hline \multicolumn{5}{|c|}{ Middle Phalangeal Hair } \\
\hline Incidence: Affected & 53.84 & 55.77 & 34.62 & 32.69 \\
\hline Non - affected & 46.15 & 44.23 & 65.38 & 67.30 \\
\hline \multicolumn{5}{|c|}{ Combination of Affected Fingers } \\
\hline 0040 & 13.46 & 15.38 & 11.53 & 7.69 \\
\hline 0340 & 28.84 & 23.07 & 11.53 & 13.46 \\
\hline 0045 & 1.92 & 3.84 & 3.84 & 1.92 \\
\hline 2340 & - & - & 1.92 & - \\
\hline 0345 & 7.69 & 11.53 & 5.76 & 7.69 \\
\hline 2345 & 1.92 & 1.92 & - & 1.92 \\
\hline
\end{tabular}

females frequency of free earlobe show relatively higher incidence $(90.38 \%)$ than the males $(76.92 \%)$. The sex variation as revealed from chi-square test (chi-square $=48.998$, d.f. $=1$, $0.01>\mathrm{P})$ is statistically significant.

Of the three digital formulae of fingers, type $4>2$ is found to occur in higher frequency in both male (right $=86.53 \%$, left $=80.76 \%$ ) and female $($ right $=86.53 \%$, left $=59.61 \%$ ). The formulae $2>4$ occur usually more frequently in female (right $=11.53 \%$, left $=30.76 \%$ ) than in males (right $=5.76 \%$, left $11.53 \%$ ). Type $2=4$ is found to occur in relatively low frequency in both male (both right and left $=7.69 \%$ ) and female (right $=1.92 \%$, left $=9.61 \%)$. Barring the case of Assamese Sikh male (chi-square = 1.10), bilateral variation in female (chi-square $=9.79$, d.f. $=2,0.01>\mathrm{P}$ ) as well as bisexual variation (chi-square $=6.46$, d.f. $=2,0.05>\mathrm{P}>0.02$ ) in them reveal significant differences.

The frequencies of digital formulae of toes reveal that type Tibial $(1>2)$ predominates and the frequency is much higher in males (right = $67.30 \%$, left $=75.00 \%$ ) than the females (right $=$ $51.92 \%$, left $=69.23 \%)$. The Fibular type $(2>1)$ shows relatively frequent incidence in females (right $=44.23 \%$, left $=26.92 \%$ ) than in males (right $=32.69 \%$, left $=23.07 \%)$. Incidence of type $\mathrm{O}(1=2)$ is very rare among them (female = $3.84 \%$, male $=1.92 \%$ ).

With regard to incidence of middle phalangeal hair, a frequency of $54.80 \%$ of males is affected, while in female the incidence of effected is $33.65 \%$ only. The variation is found to be statistically significant ( chi-square $=9.42$, d.f. $=1,0.01>\mathrm{P})$. In them mostly the third and fourth (0340) fingers are affected ( male = $25.96 \%$, female $=12.50 \%$ ) which is closely followed by fourth fingers (0040) only (male = $14.42 \%$, female $=9.61 \%$ ) .

Among the Assamese Sikh, the right type of hand clasping is dominant one, frequency being $82.69 \%$ in male and $94.23 \%$ in female. The frequency of left arm over right is higher than that of right arm over left. Such frequency in male is $62.30 \%$ while in female it is $53.84 \%$. Bisexual variation reveals non-significant differences in both the traits.

It has already been mentioned that the Assamese Sikh are the descendants of Sikh soldiers recruited from Punjab (mainly Jath), most of them came to Assam under the leadership of Chaitanya Singh. It is interesting to note that the present day Assamese Sikh population trace their ancestry from Subedar Ram Singh, one of the survivor of the contingent In course of time, they settled in Nowgong district of Assam and had 
Table 3: Percentage distribution of morphogenetic traits: Assamese Sikh and other population groups

\begin{tabular}{lccccc}
\hline Population & Sex & $\begin{array}{c}\text { Hand Clasping } \\
(R)\end{array}$ & $\begin{array}{c}\text { Arm folding } \\
(R)\end{array}$ & $\begin{array}{c}\text { Ear lobe attachment } \\
(\text { Attached })\end{array}$ & $\begin{array}{c}\text { Cerumen type } \\
(\text { Dry })\end{array}$ \\
\hline Assamese Sikh & $\mathrm{M}+\mathrm{F}$ & 88.46 & 39.42 & 16.34 & 52.88 \\
Koch & $\mathrm{M}+\mathrm{F}$ & 63.46 & 40.29 & 45.00 & 51.85 \\
Brahmin & $\mathrm{M}+\mathrm{F}$ & 89.36 & 46.81 & 21.88 & 29.41 \\
Kalita & $\mathrm{M}+\mathrm{F}$ & 88.99 & 46.02 & 22.26 & 27.68 \\
Ahom & $\mathrm{M}+\mathrm{F}$ & 86.27 & 31.37 & 35.52 & 85.00 \\
Tiwa & $\mathrm{M}$ & 98.94 & 56.38 & 87.23 & -
\end{tabular}

Source: Das, 1975, 1977; Das and Das, 1973; Das et al., 1980, 1985, 1986; Haque, 1974; Sengupta, 1982, 1987

inter-marriages with women belonging to various neighbouring indigenous communities like Koch, Tiwa and others.

The present Assamese Sikh sample stand significantly apart from the so called Jath population ( Berry and Kaur, 1991). This is mainly due to the higher incidence of phenotype $\mathrm{B}$ in the Jath population at the cost of phenotype O. However, they are not significantly different from the Tiwas ( Das et al., 1980) with whom they have frequent marital relations.

The incidence of cerumen type among them also shows remarkable affinity with the Koch (Das, 1977), a detribalized caste population who have a strong Mongoloid ethnic affinity. With regard to hand clasping and arm folding however, both the Koch ( Sengupta, 1982 ) and Tiwa ( Das et al., 1980) are found to differ significantly from them.

KEYWORDS Morpho-genetic Traits. Behavioural Traits. Assamese Sikh. Population Variation.

ABSTRACT The Assamese Sikh, a numerically small population groups living in Nowgong district of Assam was studied for some morpho-genetic and behavioural traits. The percentage frequency of these traits have been compared with available data from the neighbouring populations of Assam.

\section{REFERENCES}

Berry, V. and Kaur, H: Distribution of ABO and Rh (D) blood group system in different caste groups of Punjab. Man in India, 71: 469 - 473 (1991).

Bernstein F.: Forgestetzte untersuchungen aus der theorie der Blutgruppen. Zeitschrift fur indukt. Abstammungs $U$. Vererbungslehre, 56: 233 - 272 (1930).

Bhasin, M.K. and Khanna, A : Study of behavioural traits among nine population groups of Jammu and Kashmir. Journal of Human Ecology, 5: 131 - 134 (1994).

Bhasin, M.K., Walter, H. and Danker-Hopfe, H.: The Distribution of Genetical, Morphological and Behavioural Traits among the People of Indian Region. Kamla-Raj Enterprises, Delhi (1992).

Danforth, C.H.: Distribution of hair on the digits in man. American Journal of Physical Anthropology, 4: 189 (1921).

Das, B.M.: Inheritance of cerumen types and its importance in population studies. Man in India, 57: 305 (1977).

Das, B.M., Das, P.B. and Das, R.: The Lalungs: Their Physical Features and Bio-Social Profile (Mimeographed). Department of Anthropology, Gauhati University, Gauhati (1980).

Eveleth, P.B.: An anthropometric study of North Eastern Brazilians. American Journal of Physical Anthropology, 37: 223 (1972).

Lawler, S.D. and Lawler, I.J.: Human Blood Groups and Inheritance. Heinemann Ltd., London (1951).

Lutz, F.E.: Twin data on hand clasping: A re-analysis. Acta Genet. Med. Gamell., 10: 207 - 211 ( 1908 ).

Minami, K.: The digital formulae in Japanese Fetus II. Study on relative lengths of first and second toes. Folia Anat. Jap., 24: 295 (1952).

Powell, E.F. and Whiteney, D.D.: Earlobe inheritance. Journal of Heredity, 28: 185-186 (1937).

Sengupta, S.: Physical Anthropology of the Koch Population of North East India. Mittal Publications, Delhi (1993).

Weiner, A.S.: Observation on the manner of clasping the hands and folding the arms. American Naturalist, 66: 365-370 (1932).

Authors' Address: Jaswant Singh and Sarthak Sengupta, Department of Anthropology, Dibrugarh University, Assam, 786 004, India

E-mail: Jaswantsingh79@Yahoo.co.in 